\title{
Hormone Research in Paediatrics
}

From Developmental Endocrinology to Clinical Research

Founded 1970 as "Hormones" by M. Marois

Continued by J. Girard (1976-1995); M.B. Ranke (1996-2003);

P. Czernichow (2004-2013)

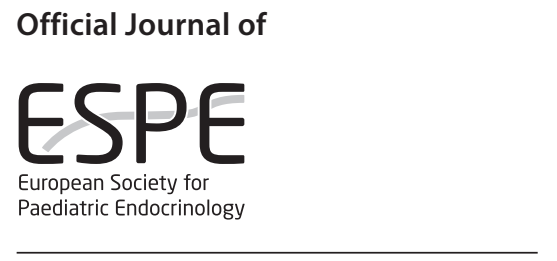

\section{PES}

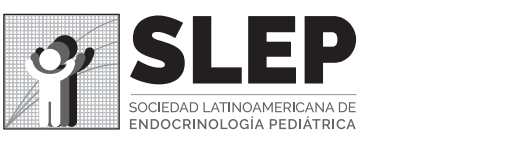

\section{Editor-in-Chief}

Stefano Cianfarani - University of Rome Tor Vergata, Rome, Italy

\section{Associate Editors}

Syed Faisal Ahmed - University of Glasgow, Glasgow, UK Ivo J.P. Arnhold - University of Sao Paulo, Sao Paulo, Brazil

Alicia Belgorosky - Hospital de Pediatría Garrahan, Buenos Aires, Argentina

Evangelia Charmandari - National and Kapodistrian University of Athens Medical

School, Athens, Greece

Mehul T. Dattani - University College London, London, UK

Andrew Dauber - Children's National Hospital, Washington, DC, USA

Johnny Deladoëy - University of Montreal, Montreal, QC, Canada

Christa E. Flück - University Children's Hospital Bern, Bern, Switzerland

Morey W. Haymond - Children's Nutrition Research Center, Houston, TX, USA

Olaf Hiort - University of Lübeck, Lübeck, Germany

Lourdes Ibañez - University of Barcelona, Barcelona, Spain

Erik Allen Imel - Indiana University School of Medicine, Indianapolis, IN, USA

Walter L. Miller - University of California, San Francisco, CA, USA

Sharon E. Oberfield - Columbia University Medical Center, New York, NY, USA

Shlomit Shalitin - Schneider Children's Medical Center of Israel, Petah Tikva, Israel

Olle Söder - Karolinska University Hospital, Stockholm, Sweden

Zdeněk Šumník - Motol University Hospital, Prague, Czech Republic

Joseph I. Wolfsdorf - Boston Children's Hospital, Boston, MA, USA

\section{Editorial Board Members}

Abdullah Bereket - Marmara University, Istanbul, Turkey

Vijayalakshmi Bhathia - Sanjay Gandhi Postgraduate Institute of Medical Sciences,

Lucknow, India

Fernando Cassorla - University of Chile, Santiago, Chile

Jean-Pierre Chanoine - British Columbia's Children's Hospital, Vancouver, BC, Canada

Francesco Chiarelli - University of Chieti, Chieti, Italy

Peter E. Clayton - University of Manchester, Manchester, UK

(Continued on next page) 


\section{Hormone Research}

\section{in Paediatrics}

(Continued)

Ethel Codner - IDIMI University of Chile, Santiago, Chile

Ellen Connor - University of Wisconsin, Madison, WI, USA

Wayne S. Cutfield - University of Auckland, Auckland, New Zealand

Preeti Dabadghao - Sanjay Gandhi Post Graduate Institute of Medical Sciences,

Lucknow, India

Cheri L. Deal - University of Montreal, Montreal, QC, Canada

Malcolm Donaldson - Royal Hospital for Sick Children, Glasgow, UK

David B. Dunger - University of Cambridge, Cambridge, UK

Michael Freemark - Duke University Medical Center, Durham, NC, USA

Maki Fukami - National Research Institute for Child Health and Development, Tokyo, Japan

Chunxiu Gong - Beijing Children's Hospital, Beijing, China

Anita C.S. Hokken-Koelega - Erasmus University Medical Center, Rotterdam,

The Netherlands

Reiko Horikawa - National Center for Child Health and Development, Tokyo, Japan

Angela Hübner - University Children's Hospital, Dresden, Germany

Kah Yin Loke - National University of Singapore, Singapore

Claudio Maffeis - University of Verona, Verona, Italy

Madhusmita Misra - Massachusetts General Hospital, Boston, MA, USA

Moshe Phillip - Schneider Children's Medical Center of Israel, Petah Tikva, Israel

Michael B. Ranke - University of Tübingen, Tübingen, Germany

Marco Aurelio Rivarola - Hospital de Pediatria Garrahan, Buenos Aires, Argentina

Scott A. Rivkees - University of Florida College of Medicine, Gainesville, FL, USA

Paul H. Saenger - NYU Winthrop Hospital, Mineola, NY, USA

Taninee Sahakitrungruang - Chulalongkorn University, Bangkok, Thailand

Mariacarolina Salerno - University of Naples, Naples, Italy

David E. Sandberg - University of Michigan Medical School, Ann Arbor, MI, USA

Martin Savage - Barts and the London School of Medicine and Dentistry, London, UK

Phyllis W. Speiser - Steven \& Alexandra Cohen Children's Medical Center of New York,

Lake Success, NY, USA

Toshiaki Tanaka - Tanaka Growth Clinic, Tokyo, Japan

Guy Van Vlieth - Sainte Justine Hospital, Montreal, QC, Canada

Rasa Verkauskiene - Kaunas University Hospital, Kaunas, Lithuania

Raimo J. Voutilainen - Kuopio University Hospital, Kuopio, Finland

Jan Maarten Wit - Leiden University Medical Center, Leiden, The Netherlands 


\section{ESPE Council}

Secretary General

A. Hokken-Koelega, Rotterdam

\section{President}

M. Dattani, London

\section{President-Elect}

S. Cianfarani, Rome

Chair of the Strategic and Finance Committee

A. Linglart, Le Kremlin-Bicêtre

Chair of Clinical Practice Committee

E. Charmandari, Athens

Chair of Corporate Liaison Board

M. Polak, Paris

Chair of Education and Training Committee

R. Hamza, Cairo

Chair of Programme Organising Committee

N. Krone, Sheffield

Chair of Science Committee

M. Cools, Ghent

Chair of Communications Committee

I. Banerjee, Manchester

PES Board of Directors

President

M. Misra, Boston, MA

President-Elect

S.E. Oberfield, New York, NY

\section{Secretary}

M. Geffner, Los Angeles, CA

\section{Treasurer}

J.S. Fuqua, Indianapolis, IN

\section{Past President}

E.A. Eugster, Indianapolis, IN

\section{At Large Directors}

P.F. Backeljauw, Cincinnati, $\mathrm{OH}$

P. Thornton, Fort Worth, TX

L.E. Cohen, Boston, MA
SLEP Council

Secretary General

R. Rey, Buenos Aires

\section{Treasurer}

G. Iñiguez, Santiago

\section{Council Members}

I.J.P. Arnhold, São Paulo

A. Belgorosky, Buenos Aires

I. Bergadá, Buenos Aires

R. Calzada, México DF

F. Cassorla, Santiago

C. Céspedes, Bogotá

C. Longui, São Paulo

A. Matallana, Cali

\section{President 2019 Meeting}

S. Antonini, Ribeirão Preto

\section{Past-President}

R. Bindels, Lima 
No. 1

Review Article

1 Short-Term Change in Measures of Glycemia in Obese Youth Meeting Criteria for Prediabetes: A Retrospective Chart Review

El Mikati, H.K.; McKinney, B.M.; Yazel-Smith, L.; Alders, S.E.; Hannon, T.S. (Indianapolis, IN)

Mini Review Article

7 The Role of MicroRNAs in Influencing Body Growth and Development

Cirillo, F.; Catellani, C.; Lazzeroni, P.; Sartori, C.; Street, M.E. (Reggio Emilia)

Research Articles

16 Identification of Transient Receptor Potential Channel 4-Associated Protein as a Novel Candidate Gene Causing Congenital Primary Hypothyroidism

Choukair, D.; Eberle, B. (Heidelberg); Vick, P. (Stuttgart); Hermanns, P. (Mainz); Weiss, B.; Paramasivam, N.; Schlesner, M.; Lornsen, K.; Roeth, R. (Heidelberg); Klutmann, C. (Mainz); Kreis, J. (Stuttgart); Hoffmann, G.F. (Heidelberg); Pohlenz, J. (Mainz); Rappold, G.A.; Bettendorf, M. (Heidelberg)

30 Hypopituitarism in Patients with Blepharophimosis and FOXL2 Mutations

Castets, S. (Bron/Marseille); Roucher-Boulez, F. (Bron/Lyon); Saveanu, A. (Marseille); Mallet-Motak, D. (Bron); Chabre, O. (Grenoble); Amati-Bonneau, P.; Bonneau, D. (Angers); Girardin, C. (Genève); Morel, Y. (Bron/Lyon); Villanueva, C. (Bron); Brue, T.; Reynaud, R. (Marseille); Nicolino, M. (Bron/Lyon)

40 McCune Albright Syndrome: Gastrointestinal Polyps and Platelet Dysfunction over 12 Years

Grob, F. (Santiago/Parkville, VIC); Zacharin, M. (Parkville, VIC)

46 Prevalence of Endocrine and Metabolic Comorbidities in a National Cohort of Patients with Craniopharyngioma

Jazbinšek, S.; Kolenc, D.; Bošnjak, R.; Faganel Kotnik, B.;

Zadravec Zaletel, L.; Jenko Bizjan, B.; Vipotnik Vesnaver, T.; Battelino, T.; Janež, A.; Jensterle, M.; Kotnik, P. (Ljubljana)

Novel Insights from Clinical Practice / Case Reports

58 Congenital Hyperinsulinism Caused by Novel Homozygous $\mathrm{K}_{\text {ATP }}$ Channel Gene Variants May Be Linked to Unexplained Neonatal Deaths among Kurdish Consanguineous Families Amaratunga, S.A. (Prague); Hussein Tayeb, T. (Sulaymani); Rozenkova, K.; Kucerova, P.; Pruhova, S.; Lebl, J. (Prague)

66 Management of Systemic Hypersensitivity Reactions to Gonadotropin-Releasing Hormone Analogues during Treatment of Central Precocious Puberty

Kirkgoz, T.; Karakoc-Aydiner, E. (Istanbul); Bugrul, F. (Konya);

Yavas Abali, Z.; Helvacioglu, D.; Kiykim, A.; Bilgic Eltan, S.; Aruci Kasap, N.; Baris, S.; Ozen, A.; Guran, T.; Bereket, A.; Turan, S. (Istanbul)
No. 2

Commentary

73 HMGB 1: A Possible Crucial Therapeutic Target for COVID-19? Street, M.E. (Reggio Emilia)

Mini Review Article

76 Minipuberty: Why Does it Happen? Becker, M. (Luxembourg); Hesse, V. (Berlin)

Research Articles

85 Sleep-Disordered Breathing in Children with Prader-Willi Syndrome in Relation to Growth Hormone Therapy Onset

Zimmermann, M. (Bonn); Laemmer, C. (Hildesheim); Woelfle, J. (Erlangen); Fimmers, R.; Gohlke, B. (Bonn)

94 A Comprehensive Multidisciplinary Management Plan Is Effective in Reducing the Prevalence of Overweight and Obesity in Childhood and Adolescence Genitsaridi, S.-M.; Giannios, C.; Karampatsou, S.; Papageorgiou, I.; Papadopoulos, G.; Farakla, I.; Koui, E.; Georgiou, A.; Romas, S.; Terzioglou, E.; Papathanasiou, C.; Kassari, P.; Manios, Y.; Charmandari, E. (Athens)

108 Effect of Testosterone Treatment for Delayed Puberty in Duchenne Muscular Dystrophy

Lee, S.L.-K.; Lim, A. (Melbourne, VIC); Munns, C. (Westmead, NSW/ Sydney, NSW); Simm, P.J.; Zacharin, M. (Melbourne, VIC)

119 Catch-Up Growth in Children Born Small for Gestational Age Related to Body Composition and Metabolic Risk at Six Years of Age in the UK

Marcovecchio, M.L.; Gorman, S.; Watson, L.P.E.; Dunger, D.B.; Beardsall, K. (Cambridge)

Clinical Practice Committee Publication

128 Outcome of Newborn Screening for Congenital Adrenal Hyperplasia at Two Time Points Eshragh, N.; Doan, L.V.; Connelly, K.J. (Portland, OR); Denniston, S. Willis, S. (Hillsboro, OR); LaFranchi, S.H. (Portland, OR)

Novel Insights from Clinical Practice / Case Report

137 Co-Existence of Congenital Adrenal Hyperplasia and Bartter Syndrome due to Maternal Uniparental Isodisomy of HSD3B2 and CLCNKB Mutations

Giri, D. (Bristol); Bockenhauer, D.; Deshpande, C.; Achermann, J.C.; Taylor, N.F.; Rumsby, G. (London); Morgan, H.; Senniappan, S. (Liverpool); Ajzensztejn, M. (London) karger@karger.com

www.karger.com

Karger ${ }^{\prime}=$
๑) 2021 S. Karger AG, Basel

Access to full text and tables of contents, including tentative ones for forthcoming issues: www.karger.com/hrp_issues 


\section{No. 3}

Publisher's Note

Mini Review Article

144 Birth Size as a Determinant of Cardiometabolic Risk Factors in Children

Nordman, H.; Jääskeläinen, J.; Voutilainen, R. (Kuopio)

Research Articles

154 Safety and Effectiveness of Omnitrope ${ }^{\circledR}$, a Biosimilar Recombinant Human Growth Hormone: More Than 10 Years' Experience from the PATRO Children Study

Pfäffle, R. (Leipzig); Bidlingmaier, M. (Munich);

Kreitschmann-Andermahr, I. (Essen); Land, C. (Gauting); Partsch, C.J. (Hamburg); Schwab, K.O. (Freiburg); Sommer, H. (Holzkirchen); Backeljauw, P. (Cincinnati, OH); Kanumakala, S. (Brighton); Loche, S. (Cagliari); Zouater, H. (Holzkirchen); Strasburger, C.J. (Berlin)

164 Arm Span and Its Relation to Height in a 2- to 17-Year-Old Reference Population and Heterozygous Carriers of ACAN Variants

Gerver, W.J.M. (Maastricht); Gkourogianni, A. (Stockholm); Dauber, A. (Washington, DC); Nilsson, O. (Stockholm/Örebro); Wit, J.M. (Leiden)

173 Growth Trajectory and Adult Height in Children with Nonclassical Congenital Adrenal Hyperplasia Wasniewska, M.G.; Morabito, L.A. (Messina); Baronio, F. (Bologna); Einaudi, S. (Turin); Salerno, M. (Naples); Bizzarri, C. (Rome); Russo, G. (Milan); Chiarito, M. (Bari); Grandone, A. (Naples); Guazzarotti, L. (Padua); Spinuzza, A.; Corica, D. (Messina); Ortolano, R.; Balsamo, A. (Bologna); Abrigo, E. (Turin); Baldini Ferroli, B. (Rome); Alibrandi, A. (Messina); Capalbo, D. (Naples); Aversa, T. (Messina); Faienza, M.F. (Bari)

Consensus Statement

182 Recommendations for Diagnosis and Treatment of Pseudohypoparathyroidism and Related Disorders: An Updated Practical Tool for Physicians and Patients Mantovani, G. (Milan); Bastepe, M. (Boston, MA); Monk, D. (Norwich); de Sanctis, L. (Torino); Thiele, S. (Lübeck); Ahmed, S.F. (Glasgow); Bufo, R (Foggia); Choplin, T. (Jouars-Pontchartrain); De Filippo, G.

(Le Kremlin-Bicêtre); Devernois, G. (Jouars-Pontchartrain); Eggermann, T. (Aachen); Elli, F.M. (Milan); Garcia Ramirez, A. (Almería);

Germain-Lee, E.L. (Farmington, CT); Groussin, L. (Paris); Hamdy, N.A.T. (Leiden); Hanna, P. (Le Kremlin-Bicêtre); Hiort, O. (Lübeck); Jüppner, H. (Boston, MA); Kamenický, P. (Le Kremlin-Bicêtre); Knight, N. (London); Le Norcy, E. (Paris); Lecumberri, B. (Madrid); Levine, M.A. (Philadelphia, PA); Mäkitie, O. (Helsinki); Martin, R. (Sao Paulo); Martos-Moreno, G.Á. (Madrid); Minagawa, M. (Chiba); Murray, P. (Manchester); Pereda, A. (Vitoria-Gasteiz); Pignolo, R. (Rochester, MN); Rejnmark, L. (Aarhus); Rodado, R. (Almería); Rothenbuhler, A. (Le Kremlin-Bicêtre); Saraff, V. (Birmingham); Shoemaker, A.H. (Nashville, TN); Shore, E.M. (Philadelphia, PA); Silve, C. (Paris); Turan, S (Istanbul); Woods, P. (London); Zillikens, M.C. (Rotterdam);

Perez de Nanclares, G. (Vitoria-Gasteiz); Linglart, A. (Le Kremlin-Bicêtre)
Clinical Practice Committee Publication

197 A Bayesian Approach to Diagnose Growth Hormone Deficiency in Children: Insulin-Like Growth Factor Type 1 Is Valuable for Screening and IGF-Binding Protein Type 3 for Confirmation

Inoue-Lima, T.H.; Vasques, G.A.; Nakaguma, M.; Brito, L.P.; Mendonça, B.B.; Arnhold, I.J.P.; Jorge, A.A.L. (São Paulo)

Novel Insights from Clinical Practice / Case Report

206 Pericardial Effusion Associated with Diazoxide Treatment for Congenital Hyperinsulinism

Hastings, L.A. (Randwick, NSW); Preddy, J.; McCready, M

(Wagga Wagga, NSW); Neville, K.; Verge, C.F. (Randwick, NSW)

212 Erratum

213 Erratum

No. 4

Mini Review Article

215 Treatment of Metabolic Syndrome in Children Tagi, V.M.; Samvelyan, S.; Chiarelli, F. (Chieti)

Research Articles

226 Congenital Adrenal Hyperplasia in Children: A Pilot Study of Steroid Hormones Expressed as Sex- and Age-Related Standard Deviation Scores

Clausen, C.S.; Ljubicic, M.L.; Main, K.M.; Andersson, A.-M.; Petersen, J.H.; Frederiksen, H.; Duno, M.; Johannsen, T.H.; Juul, A. (Copenhagen)

239 Improving Malignancy Prediction in AUS/FLUS Pediatric Thyroid Nodules with the Aid of Ultrasound Arora, S.; Khoury, J.; Trout, A.T.; Chuang, J. (Cincinnati, OH)

245 Questioning the Value of Brain Magnetic Resonance Imaging in the Evaluation of Children with Isolated Growth Hormone Deficiency

Oren, A.; Singer, D. (Tel Aviv); Rachmiel, M.; Hamiel, U. (Tel Aviv/Zerifin); Shiran, S.I. (Tel Aviv); Gruber, N.; Levy-Shraga, Y.; Modan-Moses, D. (Tel Aviv/Ramat Gan); Eyal, O. (Tel Aviv)

251 Significance of "Time below Range" as a Glycemic Marker Derived from Continuous Glucose Monitoring in Japanese Children and Adolescents with Type 1 Diabetes Urakami, T.; Yoshida, K.; Kuwabara, R.; Mine, Y.; Aoki, M.; Suzuki, J.; Morioka, I. (Tokyo) 
Novel Insights from Clinical Practice / Case Reports

258 Use of Copeptin Levels to Predict the Resolution of Transient Postoperative SIADH

Jones, B.; Corredor, M.; Lteif, A.; Pittock, S.; Bornhorst, J.; Creo, A. (Rochester, MN)

263 High Bone Mineral Density Osteogenesis Imperfecta in a Family with a Novel Pathogenic Variant in COL1A2 Graves, L.E.; Wall, C.-L.; Briody, J.N.; Bennetts, B.; Wong, K.; Onikul, E.; Biggin, A.; Munns, C.F. (Westmead, NSW)

272 Successful Use of Denosumab for Life-Threatening Hypercalcemia in a Pediatric Patient with Primary Hyperparathyroidism

Mamedova, E.; Kolodkina, A.; Vasilyev, E.V.; Petrov, V.; Belaya, Z.; Tiulpakov, A. (Moscow)

\section{No. 5}

Research Articles

279 Thyroid Volume and Thyroid Function Parameters Are Independently Associated with Weight Status in Overweight Children

Lass, N.; Barth, A.; Reinehr, T. (Datteln)

287 Adiponectin Signaling and Impaired GTPase Rab5 Expression in Adipocytes of Adolescents with Obesity Karvela, A.; Kostopoulou, E. (Patras); Rojas Gil, A.P. (Tripoli); Avgeri, A.; Pappa, A. (Patras); Barrios, V. (Madrid); Lambrinidis, G. (Athens); Dimopoulos, I. (Kalamata); Georgiou, G. (Patras); Argente, J. (Madrid); Spiliotis, B. (Patras)

297 Clinical Predictors of Transient versus Persistent Neonatal Hyperinsulinism

Falzone, N.; Harrington, J. (Toronto, ON)

304 Demographic Characteristics, Risk Factors, and Presenting Features of Children with Symptomatic Nutritional Rickets: A French Series

Flot, C.; Porquet-Bordes, V. (Paris/Toulouse); Bacchetta, J. (Paris/Bron); Rothenbuhler, A. (Paris/Le Kremlin-Bicêtre); Lienhardt-Roussie, A. (Paris/ Limoges); Giabicani, E. (Paris); Gueorguieva, I. (Paris/Lille); Storey, C. (Paris); Linglart, A. (Paris/Le Kremlin-Bicêtre); Salles, J.-P.; Edouard, T. (Paris/Toulouse)

Novel Insights from Clinical Practice / Case Reports

313 Cinacalcet as a First-Line Treatment in Neonatal Severe Hyperparathyroidism Secondary to Calcium Sensing Receptor (CaSR) Mutation

Gulcan-Kersin, S.; Kirkgoz, T.; Eltan, M.; Rzayev, T.; Ata, P.; Bilgen, H.; Ozek, E.; Bereket, A.; Turan, S. (Istanbul)

322 A Novel Mutation in Insulin-Like Growth Factor 1 Receptor (c.641-2A>G) Is Associated with Impaired Growth, Hypoglycemia, and Modified Immune Phenotypes Shapiro, M.R.; Foster, T.P.; Perry, D.J. (Gainesville, FL); Rosenfeld, R.G. (Portland, OR); Dauber, A. (Washington, DC); McNichols, J.A. (Gainesville, FL); Muir, A. (Atlanta, GA); Hwa, V. (Cincinnati, OH); Brusko, T.M.; Jacobsen, L.M. (Gainesville, FL)

335 Acromesomelic Dysplasia, Type Maroteaux: Impact of Long-Term (8 Years) High-Dose Growth Hormone Treatment on Growth Velocity and Final Height in 2 Siblings Arya, V.B.; Raj, M.; Younes, M.; Chapman, S.; Irving, M.; Kapoor, R.R.; Buchanan, C.R. (London)
No. 6

Clinical Practice Committee Publication

343 Pediatric Endocrinology in the Time of COVID-19: Considerations for the Rapid Implementation of Telemedicine and Management of Pediatric Endocrine Conditions Regelmann, M.O. (Bronx, NY); Conroy, R. (Springfield, MA); Gourgari, E. (Washington, DC); Gupta, A. (Richmond, VA); Guttmann-Bauman, I. (Portland, OR); Heksch, R. (Akron, OH); Kamboj, M.K. (Columbus, OH); Krishnan, S. (Columbus, OH/Oklahoma City, OK); Lahoti, A. (Memphis, TN); Matlock, K. (Charleston, SC)

Research Articles

351 Role of Body Weight in the Onset and the Progression of Idiopathic Premature Pubarche

Cavarzere, P.; Mauro, M.; Gaudino, R. (Verona); Micciolo, R. (Trento); Piacentini, G.; Antoniazzi, F. (Verona)

361 Age-Related Association of Calcitonin with Parameters of Anthropometry, Bone and Calcium Metabolism during Childhood

Sonntag, J.; Vogel, M.; Geserick, M.; Eckelt, F.; Körner, A. (Leipzig); Raue, F (Heidelberg); Kiess, W.; Kratzsch, J. (Leipzig)

371 Diagnostic Value of Serum Acid-Labile Subunit Alone and in combination with IGF-I and IGFBP-3 in the Diagnosis of Growth Hormone Deficiency

Ertl, D.-A. (Vienna); Chen, J. (Beijing); Gleiss, A.; Janu, D.; Sagmeister, S. Raimann, A.; Riedl, S.; Haeusler, G. (Vienna)

380 Long-Term Effectiveness and Safety of Childhood Growth Hormone Treatment in Noonan Syndrome

Rohrer, T.R. (Homburg); Abuzzahab, J. (Saint Paul, MN); Backeljauw, P. (Cincinnati, OH); Birkegård, A.C. (Søborg); Blair, J. (Liverpool); Dahlgren, J. (Gothenburg); Júlíusson, P.B. (Bergen); Ostrow, V. (Princeton, NJ); Pietropoli, A. (Zurich); Polak, M. (Paris); Romano, A. (Valhalla, NY); Ross, J. (Philadelphia, PA); Sävendahl, L. (Solna); Miller, B.S. (Minneapolis, MN)

Novel Insights from Clinical Practice / Case Reports

396 Unusual Glycemic Presentations in a Child with a Novel Heterozygous Intragenic INSR Deletion

Verdecchia, F.; Akcan, N.; Dastamani, A.; Morgan, K. (London); Semple, R.K. (Edinburgh); Shah, P. (London)

402 Severe Fibrous Dysplasia in McCune-Albright Syndrome: A Need for Continuous Surveillance

Grob, F. (Parkville, VIC/Santiago); Clark, J. (Heidelberg, VIC); Zacharin, M. (Parkville, VIC)

409 Efficacy of GLP-1 Agonist Therapy in Autosomal Dominant WFS1-Related Disorder: A Case Report Scully, K.J.; Wolfsdorf, J.I. (Boston, MA) 
No. 7-8

Mini Review Article

415 Immunological Profile and Autoimmunity in Turner Syndrome

Kanakatti Shankar, R. (Washington, DC)

Research Articles

423 Clinical Characteristics, Molecular Features, and Long-Term Follow-Up of 15 Patients with Neonatal Diabetes: A Single-Centre Experience

Abali, Z.Y. (Istanbul); De Franco, E. (Exeter); Karakilic Ozturan, E.; Poyrazoglu, S.; Bundak, R.; Bas, F. (Istanbul); Flanagan, S.E. (Exeter); Darendeliler, F. (Istanbul)

433 Birthweight Differences in Adolescent Monozygotic Twins Influence Androgens, Psychological Morbidity, and Health-Related Quality of Life

Schmitz, L.; Schulte, S.; Stoffel-Wagner, B.; Bartmann, P.; Plamper, M.; Schreiner, F. (Bonn); Woelfle, J. (Bonn/Erlangen); Gohlke, B. (Bonn)

442 Outcomes of Zoledronic Acid Use in Paediatric Conditions Lim, A.; Simm, P.J.; James, S.; Lee, S.L.-K.; Zacharin, M. (Melbourne, VIC)

453 Cortisol and Cortisone in Early Childhood in Very-Low-Birthweight Infants and Term-Born Infants de Jong, M. (Dordrecht); Cranendonk, A.; Twisk, J.W.R.; van Weissenbruch, M.M. (Amsterdam)

460 The Unique Role of 11-Oxygenated C19 Steroids in Both Premature Adrenarche and Premature Pubarche Wise-Oringer, B.K.; Burghard, A.C. (New York, NY); O’Day, P. (Ann Arbor, MI); Hassoun, A.; Sopher, A.B.; Fennoy, I.; Williams, K.M.; Vuguin, P.M.; Nandakumar, R.; McMahon, D.J. (New York, NY); Auchus, R.J. (Ann Arbor, MI); Oberfield, S.E. (New York, NY)

470 Diagnosis of Growth Hormone Deficiency in Children: The Efficacy of Glucagon versus Clonidine Stimulation Test Yackobovitch-Gavan, M. (Petah Tikva); Lazar, L. (Petah Tikva/Tel Aviv); Diamant, R. (Petah Tikva); Phillip, M.; Oron, T. (Petah Tikva/Tel Aviv)

Novel Insights from Clinical Practice / Case Reports

477 A Japanese Family with DICER1 Syndrome Found in Childhood-Onset Multinodular Goitre

Nagasaki, K.; Shibata, N.; Nyuzuki, H.; Sasaki, S.; Ogawa, Y.; Soda, S. (Niigata); Kogai, T.; Hishinuma, A. (Tochigi)

483 Isolated 17, 20 Lyase Deficiency Secondary to a Novel CYB5A Variant: Comparison of Steroid Metabolomic Findings with Published Cases Provides Diagnostic Guidelines and Greater Insight into Its Biological Role

Shaunak, M. (Southampton); Taylor, N.F. (London); Hunt, D.; Davies, J.H. (Southampton)
No. 9-10

Review Article

497 Postoperative and Long-Term Endocrinologic Complications of Craniopharyngioma

Bereket, A. (Istanbul)

Mini Review Article

510 Post-Transplantation Diabetes Mellitus in Pediatric Patients Grundman, J.B. (Washington, DC); Wolfsdorf, J.I. (Boston, MA); Marks, B.E. (Washington, DC)

Research Articles

519 Metabolic Effects of Growth Hormone Treatment in Short Prepubertal Children: A Double-Blinded Randomized Clinical Trial

Tidblad, A. (Stockholm); Gustafsson, J. (Uppsala); Marcus, C.; Ritzén, M.; Ekström, K. (Stockholm)

529 Fertility of Women Treated during Childhood with Triptorelin (Depot Formulation) for Central Precocious Puberty: The PREFER Study

Martinerie, L. (Paris); de Mouzon, J. (Le Kremlin Bicêtre); Blumberg, J. (Les Ulis); di Nicola, L. (Boulogne-Billancourt); Maisonobe, P. (Les Ulis); Carel, J.-C. (Paris); on behalf of the PREFER study group

539 Late Recovery of Parathyroid Function after Total Thyroidectomy in Children and Adults: Is There a Difference? de Jong, M.C. (London); Lorente-Poch, L.; Sancho-Insenser, J. (Barcelona); Rozalén García, V.; Brain, C.; Abdel-Aziz, T.E.; Hewitt, R.J.; Butler, C.R. (London); Sitges-Serra, A. (Barcelona); Kurzawinski, T.R. (London)

548 Socioeconomic Status Is Related to Pubertal Development in a German Cohort

Oelkers, L.; Vogel, M.; Kalenda, A.; Surup, H.C.; Körner, A.; Kratzsch, J.; Kiess, W. (Leipzig)

558 Genotypic Sex and Severity of the Disease Determine the Time of Clinical Presentation in Steroid 17a-Hydroxylase/17,20-Lyase Deficiency Kurnaz, E.; Kartal Baykan, E.; Türkyılmaz, A.; Yaralı, O. (Erzurum); Yavaş Abalı, Z.; Turan, S.; Bereket, A. (Istanbul); Çayır, A. (Erzurum); Guran, T. (Istanbul)

Novel Insights from Clinical Practice / Case Report

567 Primary Dwarfism, Microcephaly, and Chorioretinopathy due to a PLK4 Mutation in Two Siblings

Martín-Rivada, Á.; Pozo-Román, J.; Güemes, M.; Ortiz-Cabrera, N.V. (Madrid); Pérez-Jurado, L.A. (Barcelona/Adelaide, SA); Argente, J. (Madrid)

Commentary

573 For Premature Thelarche and Premature Adrenarche, the Case for Waiting before Testing Kaplowitz, P.B. (Washington, DC) 


\section{No. 11-12}

Historical Contribution

577 Measuring Insulin Resistance in Humans

Sharma, V.R.; Matta, S.T. (Bethesda, MD); Haymond, M.W. (Houston, TX); Chung, S.T. (Bethesda, MD)

Systematic Review and Meta-Analysis

589 Kisspeptin Levels in Girls with Precocious Puberty:

A Systematic Review and Meta-Analysis

Cintra, R.G.; Wajnsztejn, R.; Trevisan, C.M.; Zaia, V. (Santo André);

Laganà, A.S. (Varese); Bianco, B.; Montagna, E. (Santo André)

Mini Review Article

599 Fertility Preservation for Prepubertal Patients at Risk of Infertility: Present Status and Future Perspectives Pampanini, V. (Rome/Stockholm); Hassan, J.; Oliver, E.; Stukenborg, J.-B.; Damdimopoulou, P. (Stockholm); Jahnukainen, K. (Stockholm/Helsinki)

Research Articles

609 Early Adiposity Rebound Predicts Obesity and Adiposity in Youth with Congenital Adrenal Hyperplasia

Bhullar, G.; Tanawattanacharoen, V.K.; Yeh, M.Y.; Kim, W.S.; Vidmar, A.P.; Geffner, M.E.; Hwang, D.H.; Kim, M.S. (Los Angeles, CA)

616 Peer Review of Paediatric Endocrine Services in the UK: A Template for Quality and Service Improvement

Schulga, J. (Larbert); Mitchell, H. (Watford); Ahmed, S.F. (Glasgow); Albanese, A. (London); Warner, J. (Cardiff); Davies, J.H. (Southampton); Shaw, N. (Birmingham); Banerjee, I.; Patel, L. (Manchester)

622 Difference in Insulin Resistance Assessment between European Union and Non-European Union Obesity Treatment Centers (ESPE Obesity Working Group Insulin Resistance Project)

Chaychenko, T. (Kharkiv); Argente, J. (Madrid); Spiliotis, B.E. (Patras); Wabitsch, M. (Ulm); Marcus, C. (Stockholm)
634 The Clinical Spectrum of PTEN Hamartoma Tumor Syndrome: Exploring the Value of Thyroid Surveillance

Baran, J.A.; Tsai, S.D.; Isaza, A.; Brodeur, G.M.; MacFarland, S.P.; Zelley, K. Adams, D.M.; Franco, A.T.; Bauer, A.J. (Philadelphia, PA)

643 Neurodevelopmental and Mental Health Screening for Patients with Turner Syndrome in Pediatric Endocrine Clinics: Results of a Pediatric Endocrine Society Survey

Davis, S. (Aurora, CO); Crerand, C. (Columbus, OH); Hutaff-Lee, C.;

Thompson, T. (Aurora, CO); Tishelman, A. (Boston, MA); Samara, O.

(Aurora, CO); Umbaugh, H.; Nahata, L. (Columbus, OH); Kremen, J.

(Boston, MA)

Brief Report

651 A Comparison of Patients with Central Precocious Puberty Who Have a Pubertal versus Prepubertal Ultrasensitive LH at Presentation

Logan, L.A.; Eugster, E.A. (Indianapolis, IN)

656 Publisher Correction

657 Acknowledgement to the Reviewers

Suppl. 1

Abstracts

2020 Annual Meeting of the Pediatric Endocrine Society (PES) Forth Worth, TX, April 24-27, 2020

Program Chair: Sripriya, R. (Pittsburgh, PA)

(available online only)

Suppl. 2

Abstracts

XXIX Annual Meeting of the Latin American Society for

Pediatric Endocrinology (SLEP) and XXI Annual Congress of the Mexican Society of Pediatric Endocrinology

Mérida, Mexico, November 30 to December 5, 2020

Guest Editors: Guerra-Júnior, G. (Campinas, Brazil); Fideleff, H.

(Buenos Aires, Argentina); Mericq, M.V. (Santiago, Chile);

Torres-Tamayo, M. (Mexico City, Mexico); Aguilar-Herrera, B.E.

(Mexico City, Mexico)

(available online only)
S. Karger

Medical and Scientific Publishers

Basel $•$ Freiburg $\cdot$ Hartford $•$ Oxford $•$

Bangkok $\cdot$ Dubai $\cdot$ Kuala Lumpur .

Melbourne $\cdot$ Mexico City $\cdot$ Moscow $•$

New Delhi $\cdot$ Paris $\cdot$ Shanghai $\cdot$ Tokyo
Disclaimer

The statements, opinions and data contained in this publication are solely those of the individual authors and contributors and not of the publisher and the editor(s). The appearance of advertisements in the journal is not a warranty, endorsement, or approval of the products or services advertised or of their effectiveness, quality or safety. The publisher and the editor(s) disclaim responsibility for any injury to persons or property resulting from any ideas, methods, instructions or products referred to in the content or advertisements.

Drug Dosage

The authors and the publisher have exerted every effort to en sure that drug selection and dosage set forth in this text are in accord with current recommendations and practice at the time of publication. However, in view of ongoing research, changes in government regulations, and the constant flow of information relating to drug therapy and drug reactions, the reader is urged to check the package insert for each drug for any change in indications and dosage and for added warnings and precautions. This is particularly important when the recommended agent is a new and/or infrequently employed drug.
All rights reserved.

No part of this publication may be translated into other languages, reproduced or utilized in any form or by any means, electronic or mechanical, including photocopying, recording, microcopying, or by any information storage and retrieval system, without permission in writing from the publisher or in the case of photocopying, direct payment of a specified fee to the Copyright Clearance Center (see "General Information").

(c) Copyright 2021 by S. Karger AG,

$\mathrm{CH}-4009$ Basel (Switzerland)

Printed on acid-free and non-aging paper (ISO 9706) 